Thomas Aquinas on Natural Contingency and Providence

Abraham's Dice: Chance and Providence in the Monotheistic Traditions, Karl Giberson (ed.)

Ignacio Silva and Andrew Pinsent

The approach of Thomas Aquinas to God's action in the world was shaped in part by his engagement with the newly-received Arabic commentaries on Aristotle and the Neo-Platonic ideas present in the Liber de Causis and in Pseudo-Dionysius. Aquinas's distinct contribution, however, is a notion of Divine Providence that encompasses a view of God as first cause and a variety of contingent created causes that contribute to a richer, more perfect world. On the basis of this moderate indeterminism, justified by reference to the fourfold causes of Aristotle, Aquinas upholds a primary cause which, while causing secondary causes to cause contingently, causes their effects without determining the outcome of their contingent causing. When Aristotelian philosophy was replaced by the mechanic philosophies during the sixteenth and seventeenth centuries, the interplay between primary and secondary causes became problematic, resulting in occasionalist or deist positions.

1. Introduction: Aristotle, Neo-Platonism, and Arabic Philosophy in Aquinas' Thought

Thomas Aquinas held a strong position regarding God's providential action in the universe, its relation to the causality of natural causes, and the fact that these natural causes were contingent in their causing, chanceful, and sometimes even random. For him, God's providential action was effectuated as a primary cause through the actions of secondary created causes, which were in themselves contingent causes: for Aquinas, a providential God which allowed a world filled with contingent causes was more perfect, rendering this type of world to be more perfect than a purely deterministic world.

In the midst of the reception of Aristotelian philosophy in the high middle ages, by the midthirteenth century, Thomas Aquinas inherited the problem of God's causality within the created universe directly from the early Arabic philosophy of previous centuries. Until the twelfth century, Christian philosophy and theology had had mainly a Platonic character, following the Neo-Platonic teachings of Pseudo-Dionysius and mostly those of Saint Augustine. The early thirteenth century, however, saw the arrival of the new philosophy of Aristotle, interpreted by Islamic commentators such as Ibn-Sina (or Avicenna, 980-1037) and Ibn-Rushd (or Averroes, 1126-1198) among others, for whom one of the most important topics of discussion was the 
relationship between God as an active agent in the world and the natural causes. In this discussion they saw divine sovereignty over worldly events being clearly at stake.

Al-Ghazali (c. 1058-1111), in his twelfth-century work The Incoherence of the Philosophers, held that those who adopted Greek philosophical views were unsuccessful in achieving a coherent theory of divine action. This position was held by the Mutakallimun theologians (of which al-Ghazali was the greatest proponent), within which the Kalam theology was the main stream of thought. Kalam theologians strongly held that, if one was to take seriously the unchangeable nature of God's omnipotence and providence, then it was necessary to accept that there is no active power in nature, but that it is God who acts in every apparently natural event.

Following the Islamic religious teaching, Kalam theologians held that the universe is created out of nothing and that the universe had a beginning in time. The key issue was that they considered that God re-creates the universe at every instant, rendering creation to be an atomic event, by which God puts the whole of the universe into existence at every single moment of time, and allowing it to be rational and intelligible by keeping its regularities constant. Hence, Kalam theologians believed that all things are complete and fulfilled at any given moment of their existence: any being's becoming other is entirely dependent upon an exterior agent, capable of effecting the change, and for every change it was God who acted: the single act which produces the existence of the thing is the cause of the totality of its reality. For Kalam theologians, then, all natural change involved creation, since whatever change is effected represents the realisation of a new being entirely. In this sense, in order to accept the Koranic teaching of God's constant involvement of God in the universe, they diminished the activities of nature to the point of denying them. In brief, they admitted that there was no causality at all in nature but divine causality. Were nature to act by itself, there would be no place at all for God to act. Given their theological premises, they needed to admit that nature had no active powers at all. It was God who acted, creating every event constantly and directly without any intermediary agents, leaving created things with no causal power at all. God and God alone, by his own command and power, was the direct cause of all events in the world. This doctrine was later known as occasionalism, and was adopted by some French Cartesian authors in the early modern period like Louis de la Forge (1632-1666), Arnold Geulincx (1624-1669), Géraud de Cordemoy (1626-1684), and Nicolas Malebranche (1638-1715), as well as the English Newtonian Samuel Clarke (1675-1729).

Ibn-Rushd is perhaps the main objector to these views within the Islamic discussion on divine action in nature. Following Aristotle, he claimed that nature was autonomous in its actions, 
which meant, first that nature did not require the power of God to act, and second that God's power was somewhat diminished. In fact, his position begins by rejecting the very idea of creatio ex nibilo, because he thought that, if it were true, anything could come from anything, and there would be no congruity between effects and causes. Thus, for Ibn-Rushd, the doctrine of creation out of nothing contradicted the existence of true natural causality in the universe, and hence, the science of nature would not be possible.

This debate came to Aquinas' attention through the works of Maimonides and the Latin translations of Ibn-Rushd's Commentaries on Aristotle, and it is possible to find references to it all throughout his works, from the early Commentary on the Sentences to the later Summa Contra Gentiles, Quaestiones Disputatae De Veritate, De Potentia Dei, and the mature Summa Theologiae. ${ }^{1}$ Aquinas wants to set his own position as a middle way between the two extremes within Islamic thought, by affirming both the natural autonomy in causation together with divine action in the universe through the secondary causes, founding his argument on a very precise analysis of the notion of creation out of nothing.

It is, indeed, in Aquinas' doctrine of creation that we see one of the clearest examples of Aristotelian philosophy conjugated with Neo-Platonism in the high Middle Ages. In his exposition of the doctrine of creation out of nothing - creatio ex nibilo -, Aquinas sought to affirm the radical and continuous dependence of all things upon God as their cause (a clearly NeoPlatonic feature) and that this dependence is fully compatible with the discovery of causes in nature (one of the Aristotelian characters of his doctrine). God's omnipotence, for Aquinas, does not challenge the possibility of real causality for creatures. On the contrary, Aquinas would reject any notion of divine withdrawal from the world so as to leave room, so to speak, for the actions of creatures. Nevertheless, Aquinas does not think that God simply allows or permits creatures to behave the way they do. Creation out of nothing means that creatures are what they are, precisely because God is present to them as cause of their being and their actions continually. For Aquinas, the autonomy of nature's actions is guaranteed by God's creative continuous causality. God causes creatures to exist in such a way that they are the real causes of their own operations, being present in every operation of nature. To understand this doctrine, Aquinas emphasises that divine causality and creaturely causality function at fundamentally different levels. While God's causality is causality of creation, creature's causation is causality of change. Thus, since for Aquinas creation is not a change, these two different agents (God and creatures)

\footnotetext{
${ }^{1}$ In II Sent., d. 1, q. 1, a. 4; SCG, III, cc. 65 and 69; De Ver., q. 5, a. 2, ad 6; De Pot., q. 3, a. 7; and S. Th., I, q. 105 , a. 5.
} 
differ radically in their causing. God is the complete cause of the whole reality of whatever is, and, yet, there is in the created world a rich array of real secondary causes.

Before delving in the depths of Aquinas' thought surrounding the question of God's action in the world, it would be beneficial to revisit, even if briefly, his ideas on natural causality, as to understand how this notion relates to the distinction between primary and secondary causality, and how, through his doctrine of creation, Aquinas can provide an account of God's providence through contingent natural causes. Following Aristotle, Aquinas affirms that natural things have certain causal powers which extend to the sphere of their own kind of being. Thus fire heats, water wets, etc. In this sense natural things act according to a certain necessity which follows from their own kind of being, what medieval called nature. This feature of natural things implies a natural tendency to a determinate effect, which also implies that the effect is produced regularly so long as there are favourable circumstances for its production. Nevertheless, this characteristic does not require that, given the causes for a particular effect, this effect would always follow. It is possible to think of a natural thing that is determinate to produce a particular effect, which does so in the larger number of cases, but also that, on some occasions, it does not produce that particular effect. This failure in producing the effect might be not only because of some interactions with some external causes, but also because of an intrinsic defectiveness in the agent which expresses its contingent causal character. Even though particular things come into being and tend to develop in consistent ways, there is always the possibility of accidental, contingent or chanceful events to happen which frustrates such tendencies and renders them ultimately fruitless.

For Aquinas, then, the notion of causality does not imply a necessary relation between the cause and the effect. Instead, Aquinas would affirm that causality is better expressed in terms of a relation of dependence, in which the effect depends on the cause for its being or changing. This notion of causality as dependence opens the path to understanding causality as an analogical notion, which refers to many different kinds of causality, given that there are several ways in which something can depend upon something else in its being or change. All the kinds of causes will thus share something in common - the relation of dependence of their effects - and will also differ from each other - the way they cause.

Following Aristotle, Aquinas teaches that the causes upon which something depends can be reduced to four different kinds, which explain both why something is what it is and why it can change and become something else. As previously mentioned, these four different causes will 
cause in different ways. Thus, each of them will be that upon which something depends, even though that dependence will be with respect to different features of the thing caused. These four causes are well known: formal, material, efficient, and final causes. Two of them are extrinsic to the effect, in the sense that they determine the existence of a new being from the outside, without constituting the effect in its own being. The first of these is the final cause, which receives the name of final because it is the last one to be accomplished, and it is the one which starts (and this is why it is the first cause) and guides the action of the efficient cause or agent, which is the other extrinsic cause. The agent is that whose influx or action produces the existence the effect. It causes by producing a new determination - the form - in an already existing matter. This new form is what constitutes the new being or effect. The form is one of the intrinsic causes and the matter is the other one. These two, with their own being, constitute and cause the existence of the effect. Matter is the first intrinsic cause: it is the subject which receives the determination - the form - from the efficient cause. It is called first matter because it exists prior to the formal determination of the agent. The second intrinsic cause is the form, which is received in the matter and disposes the matter to be this or that different kind of being. Thus, the formal cause explains why a thing exists as this particular kind of thing, and the material cause explains why it can cease to be what it is and become something else. Hence, the form is usually associated with the actuality and determination of a thing, while the matter is associated with its potentiality and indetermination, becoming thus the very source of chance and randomness in the natural world.

In sum, the essence of the causal nexus, for Aquinas, is the dependence in the being or the changing of the effect upon the cause, while the modes of causality and dependency vary greatly depending on the kinds of causes involved. Causality, understood as a relation of dependence of something from the power and efficacy of its cause, becomes greatly important in Aquinas' thought when considering God's creative and provident action. Before turning our attention to Aquinas' account of God's providential action in the world, we shall consider his views on contingency in nature.

\section{Natural Contingency}

For Aquinas, natural things have a tendency to act in a particular way, according to their particular kind of being. Thus fire heats, and water wets. Aquinas asserts, then, that natural things are somehow determined to act ad unum, that is, towards one single kind of effect. 
Nevertheless, Aquinas also teaches that a natural thing may not accomplish the effect which its nature has determined it to accomplish. ${ }^{2}$ In saying this, Aquinas explicitly rejects a rigid determinism in nature, i.e. the position that whenever there is a cause a certain determinate effect necessarily follows. Aquinas finds the reason for this in the fact that natural things are contingent in their being, i.e. they can or cannot be. Hence their actions are also contingent, given that anything acts according to its being: they can fail in their natural actions.

Aquinas distinguishes between events which happen always (those which take place in the heavens), those which almost always happen, and those which happen almost never, but do happen. ${ }^{3}$ Those which occur almost always - or ut in pluribus, as Aquinas would say - existed in their causes as being almost determined, and there were no impediments in the process of causing them. These events refer to the actions of every natural being that acts. The events which occur less frequently - or ut in pancioribus - are those events which are not determined at all in their causes, but happen by accident - per accidens, or due to some sort of deficiency - propter aliquam corruptionem. Aquinas thus affirms a kind of mitigated determinism in nature. With this mitigation he does not affirm a total natural indeterminism, but the recognition that the expected effect may not be produced by the cause. So, although natural causes are necessary causes insofar as they are determined to causing one effect, they are nonetheless the source of contingency, which follows their own (limited) necessity. The root of this limited necessity is, for Aquinas, the material intrinsic co-principle, which expresses the potency to be something else of every natural being. For Aquinas, the events which express this limited necessity, those which happen 'less frequently' or ut in paucioribus, can occur due to three reasons. He explains in his Commentary on Aristotle's Metaphysics:

First, because of the conjunction of two causes one of which does not come under the causality of the other, as when robbers attack me without my intending this; for this meeting is caused by a twofold motive power, namely, mine and that of the robbers. Second, because of some defect in the agent, which is so weak that it cannot attain the goal at which it aims, for example, when someone falls on the road because of fatigue. Third, because of the indisposition of the matter,

\footnotetext{
2 SCG III, 64.

3 SCG III, 39. See also S. Th. I, 63, 9, co; In I Peri Her., XIV, 172; De Ver., 3, 1, co; De Malo, 1, 3, 17; In II De Caelo et Mundo, 9, 4; In VI Metaphysicorum, 2, 16; In VI Metaphysicorum, 3, 22; and SCG III, 99. Aquinas also refers to events which are by no means determined in their causes, making reference to human, angelic and divine free will. These types of events and their relation to divine primary causation, however, exceed the scope of this chapter.
} 
which does not receive the form intended by the agent but another kind of form. This is what occurs, for example, in the case of the deformed parts of animals. ${ }^{4}$

Thus, the three reasons reduce to 1) the encounter of many agents; 2) the weakness of the efficient cause in itself, 3) the poor disposition of patient in which the agent acts. We shall now briefly present each of these reasons.

\section{a. Due to the encounter of many agents}

Aquinas identifies the fortuitous concourse of many independent causes with the ens per accidens, which we could translate as an accidental complex or an accidental thing. ${ }^{5}$ The ens per accidens cannot be called an ens per se (a thing which is one by and of itself) ${ }^{6}$ because the ens per se only occurs where there is formal unity. ${ }^{7}$ Hence, the encounter of independent causes in a particular time and place cannot be reduced, for Aquinas, to a cause per se, simply because it does not have a cause of its own. Therefore, what comes out of this encounter is not by necessity, or determined in its causes. ${ }^{8}$ That is, given that what is per accidens is not properly speaking something with an internal unity, the event so produced can be considered as caused in a purely accidental way and thus, not having a cause properly speaking. Aquinas speaks in these cases of an accidental cause.

In this fortuitous causal concourse, the plurality of causes is indefinite, and as such it behaves as the potentiality of matter. Aquinas' arguments teach that the different causal lines which coincide in a time and space are not determined to coincide with each other. So, the causal concourse is accidental, because it has no determinate cause. It is chance which brings about the material conjunction of causes.

\section{b. Due to the weakness of the efficient cause}

The second reason that Aquinas identifies refers to the weakness of the efficient cause or agent producing the effect. As we mentioned in the introduction, Aquinas accepts that natural things are composed by two intrinsic co-principles (two intrinsic causes of things), really distinct and different: 1) the formal cause of a thing, which is the principle of being and actuality, of perfection, of determination, which determines its nature and its ways of acting; and 2) the

\footnotetext{
${ }^{4}$ In VI Met., 1. 3. See also SCG III, 99.

${ }^{5}$ Cfr. SCG III, 74.

${ }^{6}$ Cfr. S. Th. I, 116, 1, co.

7 S. Th. I, 115, 6, co.

8 S. Th. I, 115, 6, co.
} 
material cause, which is the principle of potentiality, of a passive capacity of being, which is by itself indeterminate, indifferent to being or not being, indifferent to being this or that. Natural beings, for Aquinas, are thus a mixture of actuality and potentiality, of determination and indetermination. Following Aristotle, Aquinas teaches that the origin of the defectiveness or weakness in the action of natural agents should be found in the fundamental potentiality and indetermination of matter. ${ }^{9}$

Aquinas, thus, expresses the weakness of the efficient cause in terms of the passive principle of which the material being is composed. Due to this passive principle, the active potency of natural agents could sometimes fail to produce the determined effect. Thus, the material cause of natural things, which is their passive potency, generates in them the possibility of somewhat 'escaping' from the active potency that would determine them.

\section{c. Due to the poor disposition of patient}

Aquinas also refers to the disposition (or lack of) in the being receiving the action of the efficient cause as a reason for unexpected events happening in nature. In this respect Aquinas affirms that even though the agent could act without any impediment from an external causal concourse or its own deficiency, there is still the possibility that the effect would not be produced because of the being which receives the action. Once again, the possibility to fail in the production of the effect arises from the material cause of the being which receives the action. Since no natural form completely informs the potency of the matter of a natural thing, this material potentiality can be, partially, an independent cause allowing for unexpected effects to happen.

To summarise, although natural agents act out of necessity because they are determined by their natures to cause one kind of effect, at the same time they have in their internal composition the root of contingency, i.e. their material cause. Since this cause always takes part in every natural action, it allows for the possibility that the effect which the agent determined to produce, is not perfectly caused, bringing out instead some unexpected effect. ${ }^{10}$ Thus, for Aquinas, the natural world, being composed by material beings, always includes a place for contingency and indetermination, the source which is matter, which can make events to happen per accidens. ${ }^{11}$

Aquinas, thus, asserts that nature behaves in contingent and indeterminate ways, and that the universe is not deterministic in its development. He finds three reasons for this, all of which are

\footnotetext{
9 In I Peri Herm., XIV, 183.

${ }^{10}$ In I Peri Herm., 1. 14.

11 SCG III, 86.
} 
resolved by recurring to the material cause of natural things. In nature's dynamism, the causal concourse can join the weakness of the agent, or the lack of disposition of the matter receiving the action. For Aquinas, the material cause, as an intrinsic and necessary cause of the nature of material beings, is a potential and indeterminate feature of nature that cannot be reduced in any way to the order of other three the causes. Thus, the action of natural beings, according to their formal active principle, being determined towards one kind of effect, enjoy at the same time and under a different aspect, a certain degree of indetermination.

\section{Creation and Providence ${ }^{12}$}

It is now time to turn our attention to Aquinas' doctrine of providence, through his understanding of creation. Aquinas always begins his treatment of creation out of nothing by affirming that God can make something out of nothing and that God does it. ${ }^{13}$ Since, he claims, every agent acts according to its own act, and God is absolutely and totally being in act, by His action God produces the whole subsistent being of things from nothing. This is called 'to create'. In his Summa Theologiae Aquinas makes use of Neo-Platonic terminology to address the definition of creation saying that 'the emanation of beings [from God] is called creation'. ${ }^{14}$ This understanding of creation means that the creature depends for everything in its existence upon the creator, dependence which is the very same receiving of being, in every instant of time. Hence, given that the creature depends on the creator to exist at every moment, Aquinas argues that if the giving of being - creation - would stop, the creature would cease to exist. ${ }^{15}$

From this understanding of creation out of nothing, Aquinas affirms the distinction between primary and secondary causes. Causation of being absolutely belongs to the first universal cause, God in his creative action; whereas causation of all that is in addition to being, i.e. specific being, belongs to secondary causes which act by information, i.e. by giving the form to the effect, by producing movements or changes in nature. This is, for Aquinas, the difference between the way in which God causes as primary cause, and the way in which natural things cause as secondary causes. God is the primary cause of things because what God causes is the very existence of all things, without which things would simply neither be nor act. Now, given that the very being of

\footnotetext{
${ }^{12}$ For a lengthier exposition of these ideas see Ignacio Silva, 'Revisiting Aquinas on Providence and Rising to the Challenge of Divine Action in Nature', The Journal of Religion 94:3 (2014), 277-291.

${ }^{13}$ De Pot., q. 3, a. 1, co. A similar statement is made in S. Th., I, q. 44. a. 1, co.

14 S. Th., I, q. 45, a. 1, co.

15 De Pot., q. 3, a. 14, ad 10. See also De Pot., q. 5, a. 1.
} 
the secondary cause is caused by the primary cause, all that the secondary cause is is caused by the primary cause. Therefore, its power to be a cause is also given by the primary cause: because a secondary cause has its own substance from the first cause, it likewise has its power to act from the first cause. This line of thought allows Aquinas for a very detailed account of the relation between primary and secondary causes, to which we now turn our attention.

In one of his longest analyses of divine providence, ${ }^{16}$ Aquinas holds that explaining why natural beings have causal powers requires referring to their dependence upon God's creative power. As natural things exist insofar as God gives them their being, they act insofar as God provides them with their causal power. This is the primary sense in which Aquinas understands God being the cause of the action of natural agents. Nevertheless, Aquinas makes a more detailed account by arguing for four ways in which something can be said to be the cause of the action of something else. $^{17}$

In the first place, as we just explained, something can be considered the cause of the effect of another thing when the former gives the causal power to the latter. Aquinas holds the principle that every operation which follows a certain causal power is also attributed to the giver of that causal power as its effect. Since all natural causal powers are from God, Aquinas affirms that God causes all the actions of nature, because He gives natural things the causal powers by which they act.

In second place, God is said to be the cause of a natural action because God sustains the natural causal power in its being. The principle guiding Aquinas' argument in this case says that an action that cannot continue after the influence of some agent has ceased, it should be attributed to that agent. Hence, the preserver of a causal power is said to cause the action of that power; like a remedy which preserves health is said to make a man healthy. Since God not only gives existence to things, but also preserves them in existence, God is continuously causing the causal powers in them. Therefore, every operation of a thing can be attributed to God as its cause. These two ways can be seen as founding moments of God acting in and through natural agents.

The remaining two ways can be regarded as the dynamic moments of God acting in and through natural agents. These dynamic moments allow Aquinas to account for a providential divine action through secondary causes. Thus, in third place Aquinas holds that a thing is said to cause another's action when it moves it to act, by applying another thing's causal power to action, as a

16 De Pot., q. 3, a. 7.

${ }^{17}$ See also SCG III, 67. 
man causes the knife's cutting when he applies the blade of the knife to cutting, for example, a loaf of bread. Aquinas argues in his Summa Theologiae that when natural things act, they do so by being moved by God. ${ }^{18}$ Hence, God causes the action of every natural thing by applying its power to action.

In fourth and final place, Aquinas teaches that when a principal agent causes the action of an instrument, the agent's intended effect through the instrument is attributed to the principal agent. Thus, God causes every action of all natural things. Aquinas is here referring to the causation of being itself. Since every natural thing is a being, everything which acts in a certain way causes being. ${ }^{19}$ Given that being is the most common first effect, it is an effect which belongs to God alone. Thus, God is said to be the cause of the action of natural things because in every action they somehow cause being.

Aquinas does not expand on the differences between these last two ways of causing. His analysis of instrumental causation, however, might shed some light into the matter. For Aquinas, when an agent uses an instrument, one can distinguish two different effects: the first one refers to the instrument's own causal power, while the second one refers to the agent's power, which goes beyond the power of the instrument. For example, cutting is the proper of a knife by virtue of its own sharpness. Nevertheless, when someone is using a knife, the cutting is usually in such and such manner, in a way that the knife itself cannot cut: as when a man uses a knife to cut his loaf of bread in elongated slices, which the knife by itself cannot do. Yet, the man could not cut the loaf of bread in elongated slices without the knife (or any other sharp instrument).

Aquinas observes, however, that it is through the first effect (the cutting) that the second effect (the cutting the loaf in elongated slices) is achieved. Hence this instrument, and no other, is used to accomplish this particular effect. What is more, both effects are truly caused by the instrument because the agent moves it to cause. Thus, both effects (cutting, and cutting in such a manner) can be attributed to the instrument because it is through its power that they are achieved, and they can also be attributed to the agent, because it is by its power that the instrument actually causes.

Aquinas constantly refers the analogy of instrumental causality when explaining his account of how God acts in nature through natural things, affirming that every agent in every action is an instrumental cause of God's action. Having the previous analysis of instrumental causality in

${ }^{18}$ As explained in $S T h$, I, 2, 3, co.

19 SCG III, 67. 
mind, we can see that in Aquinas' account of God's providential action through natural agents, God applies the natural agent's causal power both to achieve its own natural effect (in our example, the cutting of the knife), and to produce something that goes beyond the natural agent's own causal power (the cutting in elongated slices). That which goes beyond the natural agent's causal power is the instantiation of being, which is only attributable to God, because only God can cause being. Nevertheless, God causes being by acting as the primary agent in the actions of the natural created causes. Yet, the instrumental cause is truly the cause of the second effect (the instantiation of being) while it causes its natural effect, by receiving the power to cause this second effect from the principal agent. ${ }^{20}$

Then, both the first and second effects of the natural (instrumental) cause are achieved by receiving the power from the principal agent. The knife is moved by the man to cut, and to do it in such a manner. Without the man's power, the knife could not cut, but without the edge of the knife the man could not cut in this manner. In a similar way, God moves the natural agent to cause its own natural effect and achieves an effect which goes beyond the power of that natural agent. Thus Aquinas affirms that "the effect does not follow from the first cause, unless the secondary cause is present." 21 Therefore, Aquinas can also say that in some sense the secondary (instrumental) cause determines the action of the primary cause toward this particular effect. ${ }^{22}$ Aquinas concludes from his analysis that even though the divine will is unfailing, some of its effects are necessary while some are contingent. ${ }^{23}$

For Aquinas, then, God can be said to work in and through every natural agent inasmuch as he gives everything the causal power to act, preserves that causal power in being (founding moments), applies the causal power to action, and inasmuch as by his power every other causal power acts (dynamic moments). In a sense, for Aquinas the created causal powers of natural things require the divine power and, at the same time, are enough in their own account, since God and natural agents act on two different levels. ${ }^{24}$ The whole effect proceeds from each, yet in different ways: just as the whole of the one same effect is ascribed to the instrument, and again the whole is ascribed to the principal agent. For this reason the same effect is said to belong to the natural cause and to God. Like a craftsman gives his axe the sharpness as a permanent form,

\footnotetext{
20 Aquinas also explains this relation by using the Neo-Platonic language of participation. He argues that by participating in the power of the principal agent to produce the second effect, the instrument participates in the power of the principal agent to produce its own effect, which is what he means when saying that the principal agent applies the powers of the instrument to its own (the instrument's) effect. See De Ver., 5, 9, 7.

${ }^{21}$ De Ver., 5, 9, 12.

${ }^{22}$ De Ver., 5, 9, 10.

${ }_{23}$ In Peri Herm. I, lect. 14.

${ }^{24}$ De Pot., 3, 7, 1 and STh, I, 105, 5, 2.
} 
but not his acting power, Aquinas argues that God gives natural things the power to perform their operations according to their own natures and moves them to act.

Finally, it is important to remark that Aquinas did not think that there are four different actions in God with respect to creation. On the contrary, Aquinas presents a four-fold account of God's unique and sole action. Ultimately, the dynamic moments present God's continuous providential involvement in the history of the universe. In this respect it should be reminded that Aquinas always frames this account within his doctrine of analogy, and so it should be taken and understood as such, without asking more than it can provide: the idea that the effect is completely produced by God and by the natural agent, as a man using a knife produces two pieces of bread from just one.

\section{Providence and Contingency}

Aquinas's doctrine of creation leads to an account of providence which accounts for an autonomous natural causality which, while being contingent to a certain respect, at the same time depends completely upon God's causal powers. Thus, Aquinas conceives God as acting constantly, intimately, and providentially in and through every activity of natural agents, fully involved in the development of the history of the universe and humanity.

The key feature of Aquinas' account of a provident act is to order it towards an end. ${ }^{25}$ Hence, following his four-fold account of God's action in the created world, Aquinas teaches that God's providence, first, reaches all created being because God orders all beings to its end, but not only the totality of the universe as such. God's providence rules each singular event in its own individuality, by and through secondary causes. ${ }^{26}$ God's causality extends not only to the ways in which nature works, but also to the singular particular beings. Each singular being is directed by God's primary causality, which means that everything which is created is providentially guided by God. Nevertheless, Aquinas also argues that natural agents are the real causes of their effects since God, as the first cause of the existence of each being, is also the first cause of the causal powers of that being.

25 SCG III, 73, and STh, I, 22, 1, co.

${ }_{26} S T h$, I, 22, 2, co., and De Pot., 6, 6, co. 
Aquinas teaches, then, that God acts in and through each natural agent in order to achieve effects which transcend the causal powers of the natural created causes. Given that God acts in each action of each natural agent and that in every act God follows his reason and will, these actions are provident actions. This account, however, does not require to deny or to diminish the action of natural agents. God providentially influences the course of nature with his will and reason, by moving the secondary causes to cause and to achieve the goals that he seeks for the universe. Aquinas, thus, strongly argues for a God who is so powerful that allows secondary causes to be real causes, even contingent causes, of his providential action.

Aquinas characterises God's providential activity as having two main features: the planning and the execution of that plan. The planning belongs to God's intelligence, while the execution to God's will, ${ }^{27}$ which is performed, as we have argued so far, in and through created natural causes. Yet, since every action of natural agents can be attributed to God in the four-fold manner already explained, Aquinas affirms that "that which comes from the operation of the secondary causes is subject to the divine providence, ${ }^{28}$ meaning that it is God acting through every natural cause to achieve his goals. For Aquinas, God is thus continuously and providentially active in the universe: "God acts in all secondary causes, and their effects are to be referred to God as their cause: thus anything which is done in these individuals is His own work." 29

As we expressed in the first paragraphs of this chapter, Aquinas thinks that his account of divine providence requires the created world to include some measure of contingency and randomness in the production of the effects of natural efficient causes. Aquinas' universe is a universe of a gradual hierarchy of being, in which all modes of being (and causing) should be included. Thus, the universe would be imperfect if contingent and indeterminist causality was not included in it. There are beings which act out of necessity as well as beings which have a stronger inclination towards indeterminism in the production of their effects. For Aquinas, then, the created universe, which shows all the power of God, is a more perfect universe, including things which act of necessity and things which act contingently, which can fail in their action some times. ${ }^{30}$

Hence, Aquinas makes the final step arguing that, even when he affirms God's providential actions through created natural causes, divine providence does not exclude the contingent mode

\footnotetext{
27 SCG III, 71.

28 SCG III, 77.

29 SCG III, 75.

30 SCG, 74: "It would be against the perfection of the universe if there was nothing corruptible, or if no power would fail [in producing its effect]."
} 
of causing, thus making the universe more perfect. ${ }^{31}$ Aquinas includes in this account not only his doctrine on the human free will, but mostly his teachings on the contingent natural actions which we have reviewed earlier, i.e. those events which happen out of the contingent activity of natural agents. The basic idea is that even when God causes each natural action, these natural agents are truly contingent in their activity and in their causal capacities, being able, potentially, to fail in the realisation of the determined effect of their natures. After all, the principal agent assumes the nature of its instrument to act with it.

In order to explain how these contingent events relate to God's providential action, Aquinas explains that natural agents relate to divine providence in two different ways: 1) as ordered to itself, i.e. to their created natures, and 2) as ordered to something else, i.e. to the effect of the divine providence. Events which happen as they were determined in their causes fall under both ways of understanding providence: they are according to what was expected from them and in doing so they are also guided by the divine will and wisdom. On the other hand, events which happen due to the failure of the agent (those which Aquinas referred to as happening ' $u$ t in paucioribus') fall only under the second way of understanding the providential act. ${ }^{32}$ In this case, the event was not determined in its cause but nevertheless happened as a random event, truly contingent within the created natural world. Nevertheless, Aquinas argues that it is also guided by the divine providence because it is caused by God as its first cause in the four ways we analysed. Thus, Aquinas affirms that God, even by means of a created, contingent in its action, natural agent (which can be described as a deficient instrument in the analogy used earlier), achieves his goals and intentions by causing it to cause contingently, randomly. As in instrumental causality the principal agent has goals which are not included in the causal power of the instrument but which are nevertheless achieved, God, as principal agent, even when acting through contingent causes, reaches his own goals.

Aquinas, then, argues that from a contingent, indeterminate or random cause, God can accomplish something better in the universe. In fact, he also claims that even though the contingent effect was not determined in its causes (because it was cause by a failing natural cause), God's goals do include those effects, which are ordered to new good things in the universe. In this way, Aquinas's ideas help solve the question about events happening outside the ordinary course of nature by explaining that even those which happen randomly or by chance are providentially guided by God's continuous action.

31 SCG III, 72, and in 74 "It is against the notion of divine providence that there is nothing casual or random in things."

32 De Ver., $5,4$. 


\section{Conclusion}

Aquinas inherited the discussions on divine activity in the world in relation to natural causes from his Arabic Aristotelian and anti-Aristotelian predecessors. Addressing this issue with a synthesis of Neo-Platonic and Aristotelian philosophies, Aquinas was able to produce a sophisticated account of God's action and its relation with the action of natural created contingent causes. Aquinas affirms four different ways in which God can be attributed with an effect of a natural cause. Starting with the founding moments of God's acting in nature Aquinas says that God causes the natural agent's effect because God is the cause of the natural agent's causal power to cause that effect. Second, in the same way in which Aquinas distinguishes between creation and conservation, God also maintains those causal powers in existence. Hence God is said to be the cause of what is caused by those causal powers.

Aquinas introduces the analogy of instrumental causality when discussing the dynamic moments of God's acting in nature. In these moments, God applies the power of the natural being to act and uses the natural agent in its action to produce an effect which goes beyond the natural agent's power, strongly holding that both effects of the secondary cause can be attributed completely to God and completely to the natural agent. ${ }^{33}$

In what can be seen an unexpected move, Aquinas affirms that the created universe is more perfect because it includes imperfect contingent causality, i.e. natural causes which do not determine the effect in its totality. Nevertheless, Aquinas does not want to say that it is God who somehow completes that lack of efficient power. On the contrary, Aquinas is convinced that, given his account of primary and secondary causation, God accomplishes his intentions through the contingency of the created causes, firmly asserting that God acts within this contingency precisely by allowing causes to cause contingently.

The dismissal of Scholastic Aristotelian philosophy and theology during the sixteenth and seventeenth century in Northern Europe implied a re-affirmation of the divine omnipotence, which brought a rejection of the Aquinas' analysis of primary and secondary causation. New approaches to causation rejected the notions of chance, random events, and contingent natural causes. In order to exalt divine sovereignty over worldly events, the theology of the Reformed

${ }^{33}$ De Pot., 3, 7, co. 
Calvinist Tradition, as Byung Soo Han explains in chapter five, denied the existence of truly random and chanceful events in nature.

On the philosophical side of the rejection of Aristotelian philosophy, the champions of the mechanical philosophy of nature of the seventeenth century, by rejecting the idea of forms of natural things and adopting an atomistic view of matter, also rejected the Thomistic ideas on primary and secondary causation. Nevertheless, far from following the tradition of atheism which was attached to atomism, as John H. Brooke explains in chapter seven, Descartes, Newton, and Kepler, in the companion of many other natural philosophers, developed new views of divine providence and sovereignty over nature. Given their atomic view of nature, these views tended to deny real causal powers in natural things, allowing for God to govern the behaviour of nature through his eternal and immutable laws. 